\title{
THE CIRCULATING LIPIDS AND LIPOPROTEINS IN CORONARY ARTERY DISEASE
}

By M. F. Oliver, M.B., M.R.C.P.E., and G. S. Boyd, Ph.D.

From the Department of Cardiology, Royal Infirmary, Edinburgh and the Department of Biochemistry, University of Edinburgh

In 1856 Virchow stated that atheromatous lesions were probably due to primary imbibation from the passing blood resulting in fatty metamorphosis in the connective tissue ground substance of the arterial intima. Cholesterol had been demonstrated microscopically in atherosclerotic plaques nine years previously (Vogel, I 847) and since 1913, when Anitschkow and Chalatow succeeded in producing the typical picture of atherosclerosis by feeding rabbits with pure cholesterol in vegetable oil, there has been increasing evidence of an association between cholesterol and fat metabolism with atherogenesis. The lipid composition of atherosclerotic plaques and of plasma is similar enough to suggest that the lipids of the plaques may have their origin from the plasma (Weinhouse and Hirsch, r940; Buck and Rossiter, I95I), and labelled cholesterol studies have shown that this plasma lipid can be incorporated into atherosclerotic plaques in man (Biggs, Kritchevsky, Colman, Gofman, Jones, Lindgren, Hyde and Lyon, 1952). Attention has therefore been focused on the nature and characteristics of the circulating lipids.

\section{The Circulating Lipids}

I. Neutral Fats. These are triglycerides of various saturated and unsaturated fatty acids containing even numbers of carbon atoms. The chief function of neutral fat appears to be a concentrated reserve of energy. Chylomicrons are largely derived from chyle and are aggregates of neutral fat molecules, which are visible in plasma as they measure approximately $I$ micron in diameter. They can be used as a measure of fat absorption.

2. Fatty Acids. Neutral fats, esterified cholesterol and the compound lipids all contain fatty acids, which also circulate in a chemically 'free' form although physically bound to certain proteins.

(a) Non-essential fatty acids are mostly saturated and are synthesized from active acetate (acetylCoenzyme A) derived from fat, protein and car- bohydrate. Examples of fatty acids in this category are palmitic acid $\left(\mathrm{C}_{16}\right)$ and stearic acid $\left(\mathrm{C}_{18}\right)$.

(b) Essential fatty acids cannot be synthesized by the body and must be obtained from the diet. They are principally linoleic, linolenic and arachidonic acids which contain two, three and four double bonds respectively. Of the three main circulating lipids, neutral fat, cholesterol and phospholipids (lecithin), the fatty acids of cholesterol esters are the most unsaturated (iodine number ${ }_{15} 8$ ) and are probably largely of the essential category. Up to the present time a deficiency of any so-called essential fatty acid has not been conclusively related to any specifico clinical feature in man.

3. Sterols. Cholesterol makes up between 950 per cent. and 98 per cent. of the circulating sterols and there are also minute quantities of dihydrocholesterol and 7-dehydrocholesterol in circulation. Cholesterol occurs in the plasma in two forms: approximately 30 per cent. as 'free' cholesterol, when the hydroxyl group is unesterified and therefore can be precipitated by digitonin, and approximately 70 per cent. as ester cholesterol when it is esterified with unsaturated fatty acids. Sperry (1936) has indicated that the ratio of ester to total cholesterol is remarkably constant. Cholesterol is not essential in the diet; it is synthesized from acetyl-Coenzyme A primarily in the liver and is therefore derived from all three dietary elements.

4. Compound Lipids. Many of these contain phosphorus and all include fatty acids in their structure. Phospholipids or phosphatides are usually classified into lecithins, cephalin and sphingomyelin. Lecithins contain the base choline and make up approximately 80 per cent. of the plasma phospholipids, and cephalins contain the base ethanolamine.

\section{The Circulating Lipoproteins}

For many years the clarity of serum and plasma has suggested that its lipid content is stabilized in 
solution by linkage to protein, and in 1929 Macheboeuf indicated the presence of lipidprotein complexes by his isolation from serum of a substance which contained a reproducible proportion of nitrogen and lipid. It is now generally believed that neutral fat, cholesterol (free and esterified forms) and phospholipids are transported in the circulation combined with one another and with protein in macromolecular complexes called lipoproteins.

The properties and structure of the lipoproteins, and the enzyme systems involved in their interaction, have not yet been defined but they are known to differ in chemical constitution, in solubility, in molecular size, and in isoelectric point. Essentially all of the cholesterol and phospholipids present in serum has been demonstrated in the electrophorectically separated $\alpha_{1}$ and $\beta_{1}$ globulin fractions (Blix, Tiselius and Svensson, 194I). The circulating lipoproteins have been subjected to three principle analyses.

I. Zone Electrophoresis. This technique (Wieland and Fischer, 1948; Durrum, 1950), based on the different rates of migration of the protein fractions in a buffer in an electric field, permits isolation of each protein component of the serum in a fairly pure state. Staining techniques (Swahn, 1952, I953) using Sudan III or IV, Sudan black, or Oil red $\mathrm{O}$ have demonstrated the presence of two lipid bands corresponding to the $\alpha$ and $\beta$ globulins. Actual chemical analysis of the serum lipoproteins can be obtained by electrophoresis in a starch block or on filter paper with subsequent elution of cholesterol and phospholipids (Nikkilä, I953; Boyd, 1954).

2. Low Temperature Ethanol Fractionation. This procedure, which involves elaborate protein fractionation, separates the circulating lipoproteins according to their physicochemical properties into two main groups called the IV-I group, which contains $\alpha$-lipoproteins, and the III-O group, which contains $\beta$-lipoproteins (Cohn, Gurd, Surgenor, Barnes, Brown, Derouaux, Gillespie, Kahnt, Lever, Liu, Mittelman, Mouton, Schmid and Uroma, 1950; Russ, Eder and Barr, 1951).

3. Ultracentrifugation. The ultracentrifuge produces a force many thousand times that of gravity and large molecules, such as lipoproteins, are induced to undergo flotation or sedimentation according to the relative density of the molecules and the medium. When the density of the serum sample is adjusted to 1.063 and submitted to ultracentrifugation, all molecules of a lower density float to the surface and are termed the low density lipoproteins. Those lipoproteins, which remain in the infranatant at a density of r.063, float to the surface when the density of the serum is readjusted to 1.07 and 1.12 and sub- mitted to further ultracentrifugation and are termed the high density lipoproteins. The concentration of these lipoproteins can be determined by a photographic procedure during ultracentrifugation (Gofman, Lindgren and Elliot, 1949; Lindgren, Elliot and Gofman, 195 I). In general, the low density lipoproteins correspond to the $\beta$-lipoproteins and the high density lipoproteins to the $\alpha$-lipoproteins. This technique has demonstrated that the low and high density lipoproteins can each be resolved into several classes.

\section{The Cholesterol: Phospholipid (C/P) Ratio}

The ratio of the circulating cholesterol to the circulating phospholipids is reasonably constant in health (Peters and Man, 1943) and there is evidence to indicate that the phospholipids have a stabilizing effect on the colloidal dispersion of cholesterol (Boyd, 1937). The degree of visible lipaemia appears to be inversely related to the lecithin content of the serum (Ahrens and Kunkel, 1949), and thus the translucency of the serum is dependent not only on the lipid-protein attachments but also on the ratio of cholesterol to phospholipid within the macromolecule. The average cholesterol:phospholipid ratio ( $\mathrm{C} / \mathrm{P}$ ratio) of whole plasma is approximately 0.85 in health, the $\mathrm{C} / \mathrm{P}$ ratio of the $\beta$-lipoproteins (low density lipoproteins) is approximately 1.25 and the $C / P$ ratio of the $\alpha$-lipoproteins (high density lipoproteins) is approximately 0.55 . The $\mathrm{C} / \mathrm{P}$ ratio of whole plasma is derived from the $\mathrm{C} / \mathrm{P}$ ratio of the two major groups of lipoproteins and is dependent on the ratio of one lipoprotein to the other.

\section{The Circulating Lipids and Lipoproteins in Health}

The liver is the chief site of the biosynthesis of cholesterol and phospholipids and is intimately involved in their removal from the circulation.

Allowing for variations in analytical techniques, the normal values for the circulating lipids and lipoproteins are expressed in Table $\mathrm{I}$.

\section{Age}

The circulating lipids are influenced by age, and after birth there is a fairly rapid rise in plasma cholesterol from approximately $50-70 \mathrm{mg} . \%$ to the region of $130-150 \mathrm{mg} . \%$ at about the end of the first month. Most authorities agree that there is a gradual rise up to the age of 30 , but there is no general agreement as to whether this rise continues or not (Page, Kirk, Lewis, Thompson and Van Slyke, 1935; Keys, Mickelsen, Miller, Hayes and Todd, 1950). At all events, the increase in cholesterol is not very marked and is probably not an obligatory concomitant of ageing (Sperry and Webb, 1950). 
Table 1.-The Approximate Ranges of The Circulating Lipids and Lipoproteins in HEALTh

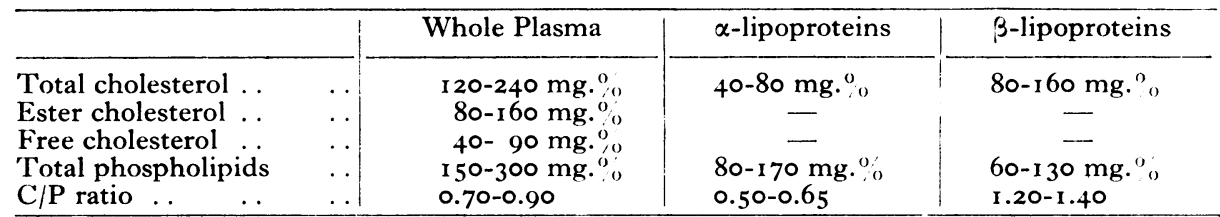

Table 2.-The Development of Atherosclerotic Lesions in Different Species is Closely Related to the Concentration of Cholesterol on the $\beta$-Lipoproteins

\begin{tabular}{|c|c|c|c|c|}
\hline & & $\begin{array}{l}\text { Cholesterol } \\
\text { in mg. \% } \\
\text { (approximate) }\end{array}$ & $\begin{array}{l}\% \text { Cholesterol } \\
\text { on the } \\
\beta \text {-lipoproteins }\end{array}$ & Atherosclerotic Lesions \\
\hline $\begin{array}{l}\text { Human: } \\
\text { Coronary disease } \\
\text { In health } \quad .\end{array}$ & $\begin{array}{l}\cdots \\
\cdots\end{array}$ & $\begin{array}{l}240 \\
180\end{array}$ & $\begin{array}{l}90 \\
70\end{array}$ & \} Spontaneous atherosclerotic lesions \\
\hline Rabbit & . & +o & 50 & With cholesterol feeding only \\
\hline Dog & . & 140 & 30 & With cholesterol feeding - thyroid depression \\
\hline Rat & .. & 50 & 10 & Rarely produced \\
\hline
\end{tabular}

Table 3.-The Approximate Ranges of the Circulating Lipids and Lipoproteins in Coronary Artery Disease

\begin{tabular}{|c|c|c|c|c|c|c|}
\hline & & & & & $\begin{array}{c}\text { Coronary Artery } \\
\text { Disease }\end{array}$ & Normal \\
\hline Total cholesterol & . & . & . & . & $200-300 \mathrm{mg} . \%$ & $120-240 \mathrm{mg} . \%$ \\
\hline $\mathrm{C} / \mathrm{P}$ ratio & . & $\cdots$ & . & $\cdots$ & $0.85-1.10$ & $0.70-0.90$ \\
\hline \multicolumn{5}{|c|}{ Cholesterol on the $\beta$-lipoproteins } & $80-100$ & $60-85$ \\
\hline \multicolumn{5}{|c|}{ Sf 12-400* class of low density lipoproteins } & $270-320 \mathrm{mg} . \%$ & $215-240 \mathrm{mg} \cdot \%$ \\
\hline
\end{tabular}

* The $S_{\mathrm{f}} 12-400$ class is the subdivision of the ultracentrifugally determined low density lipoproteins most frequently and markedly elevated in association with clinical coronary disease.

Sex

Random determinations carried out in young men and young women are not markedly different, but the circulating lipids and lipoproteins are influenced by sex in so far as there is a cyclical variation with the menstrual cycle (Oliver and Boyd, I953a, 1955c). At ovulation the plasma cholesterol and cholesterol attached to the $\beta$-lipoproteins are lower than during the follicular and luteal phases. In the third trimester of pregnancy, there is considerable hypercholesterolaemia and an increase in the concentration of cholesterol on the $\beta$-lipoprotein fraction (Oliver and Boyd, 1955a).

\section{Race}

It is difficult to dissociate the effect of primary racial characteristics from racial dietetic habits and therefore racial differences in the circulating lipids and lipoproteins are probably largely related to diet and economy. Recent epidemiological studies in numerous countries and races have suggested a direct relationship between an increase in the consumption of dietary fat and improvement in economic position with an increase in circulating cholesterol levels and an increasing incidence of clinical coronary artery disease. Study of the circulating lipids and lipoproteins in relation to the dietetics of contrasting racial $₹$ groups may add to the understanding of the 을 racial and geographic distribution of arterial disease.

\section{Diet}

Excessive intake of cholesterol (Keys, Anderson, N Mickelson, Adelson and Fidanza, 1956) does not $\mathrm{N}$ increase the circulating cholesterol but an increase in the intake of animal fat elevates the circulating cholesterol (Anderson and Keys, 1953). However, if the intake of vegetable fat is increased, $\stackrel{\circ}{+}$ then there is a decrease in plasma cholesterol, the $\mathrm{C} / \mathrm{P}$ ratio and the cholesterol attached to the 
$\beta$-lipoprotein fraction (Kinsell, Michaels, Partridge, Boling, Balch and Cochrane, I953; Beveridge, Connell, Mayer, Firstbrook and De Wolfe, I955; Bronte-Stewart, Antonis, Eales and Brock, I956). Reduction of total dietary fat will also lower these values (Mellinkoff, Machella and Reinhold, I950), but complete starvation causes mobilization of fat reserves, lipaemia, an increase in the circulating cholesterol, and the $\mathrm{C} / \mathrm{P}$ ratio (Kartin, Man, Winkler and Peters, 1944) and an increase in low density lipoproteins (Rubin and Aldayem, I954).

\section{The Circulating Lipids and Lipoproteins in Arterial Disease \\ Experimental Atherosclerosis}

In many species the production of hypercholesterolaemia from cholesterol feeding results in the deposition of cholesterol in the aortic and arterial intima and media. In general, the magnitude and number of these experimental lesions is proportional to the degree of hypercholesterolaemia (Anitschkow, I933; Katz and Stamler, 1953). On cessation of cholesterol feeding in the dog and the chick there is a rapid return of blood cholesterol to normality and regression of cholesterol deposits. Arterial lesions result from the intravenous administration to normal rabbits of hypercholesterolaemic plasma from cholesterol-fed rabbits (Bragdon, I95I) and also the parenteral administration of cholesterol emulsions (Pollak, 1949). The production of hypercholesterolaemia by means other than cholesterol feeding, such as the administration of large doses of oestrogens to chicks, is followed by deposition of cholesterol in the arterial wall. Thus the study in animals and birds of arterial lesions, which are morphologically closely comparable to the human lesion, has served to emphasize the association of hypercholesterolaemia with their production. There is very considerable species difference in the cholesterol concentration on the lipoproteins and it is instructive to observe how the cholesterol attached to the $\beta$-lipoprotein fraction increases in parallel with the ease with which atherosclerotic lesions occur (Table 2).

\section{Clinical Coronary Disease}

Until recently it was thought that man and rabbits differed in their atherogenic process in so far as the presence of excess cholesterol in human blood had not been conclusively demonstrated in association with atherosclerotic disease (Ophüls, I933. More recent investigations have shown beyond reasonable doubt that there is considerable derangement of the circulating lipids in patients who have clinical evidence of coronary artery disease (Table 3) (Gertler, Garn and Lerman,
I950; Morrison, Gonzalez and Wolfson, I950; Steiner, Kendall and Mathers, I952; Oliver and Boyd, 1953b). The mean plasma total cholesterol is increased by about 30 per cent. and the $\mathrm{C} / \mathrm{P}$ ratio is increased by approximately $\mathrm{I} 5$ per cent. and, when cholesterol and phospholipids are both expressed in $\mathrm{mg} . \%$, the $\mathrm{C} / \mathrm{P}$ ratio is not infrequently greater than unity. The hypercholesterolaemia and elevated $\mathrm{C} / \mathrm{P}$ ratio observed in clinical coronary artery disease are both consequent upon an increase in the concentration of cholesterol on the $\beta$-lipoprotein fraction (e.g. increased low density lipoproteins) and a decrease in the concentration of cholesterol on the $\alpha$-lipoprotein fraction (e.g. decreased high density lipoproteins) (Table 3 ) (Barr, Russ and Eder, I95I; Jones, Gofman, Lindgren, Lyon, Graham, Strisower and Nichols, I95I; Nikkilä, I953; Rosenberg, Young and Roger, 1954; Gofman, Glazier, Tamplin, Strisower and De Lalla, 1954; Oliver and Boyd, 1955b). The most marked derangement of these circulating lipids and lipoproteins occurs in subjects who develop clinical coronary disease under the age of 40 suggesting the possibility that the presence of a defect in lipid metabolism may predispose to the early development of this condition. Alteration of the circulating lipids and lipoproteins in subjects presenting with cerebral or peripheral vascular disease has not yet been established, although our investigations suggest that there is both hypercholesterolaemia and an increase in the cholesterol on the $\beta$-lipoprotein fraction, although less marked than in coronary disease. One of the chief problems in investigations on subjects with cerebral and peripheral vascular disease is that it is seldom possible to be sure that they do not have coexisting coronary atherosclerosis of an advanced degree. A preliminary study on subjects presenting with acute cerebral vascular accidents indicates that more than half have abnormal electrocardiograms and a considerable number had electrocardiographic evidence of myocardial infarction (Oliver).

The biochemical analyses of plasma and serum, while important to the investigation of the problems of atherosclerosis, in themselves are insufficient to allow accurate prediction of incipient clinical coronary disease. In our experience a very high proportion of patients with established coronary disease have elevation of the plasma cholesterol, the $\mathrm{C} / \mathrm{P}$ ratio or the cholesterol concentration on the $\beta$-lipoprotein fraction; indeed, in a group of 80 subjects under the age of 40 , only five had entirely normal patterns. On the other hand, a few clinically healthy subjects have shown abnormal lipid and lipoprotein patterns and only time will reveal whether they had incipient clinical coronary disease when the 
observations were made. Gofman, Glazier, Tamplin, Strisower and De Lalla (1954) have defined an 'atherogenic index' from a study of the ultracentrifugal lipoprotein pattern. While this index may be statistically sound for group studies, its application for the prediction of the development of clinical coronary artery disease in a given individual requires further detailed appraisal. This may be just as well, because at present there is not a great deal which can be done to prevent its development.

\section{Treatment}

On the grounds that clinical coronary artery disease is associated with a defect in lipid metabolism, it is logical to attempt to correct the elevated circulating lipids and lipoproteins. These values can be reduced by dietary measures. A diet deriving less than I 5 per cent. of its total calories from fat will result in decrease, which is in the region of 15 per cent. in the circulating lipids and lipoproteins but this is only achieved by rigorous adherence to a very unpalatable monotonous regime. Similarly, reduction in the elevated circulating lipids and lipoproteins has been observed following the administration of $\beta$-sitosterol, a plant sterol closely related to cholesterol. Recent experimental studies have shown that the ingestion of certain essential fatty acids (unsaturated fatty acids from vegetable oils) can result in correction of the abnormal circulating lipids and lipoproteins.

Oestrogens in suitable doses are reasonably tolerated by most men and achieve a decrease in plasma cholesterol and $\beta$-lipoprotein cholesterol of about 30 per cent. Thyroid derivatives depress these values, but, with the exception of some of the newer thyroxine analogues, this depression is usually associated with an increase in the metabolic requirements.

Whatever method is chosen for correction of the elevated lipids and lipoproteins in clinical coronary disease, it is fundamental to determine whether such correction will be associated with inhibition or even regression of the atherosclerotic lesions. It should be remembered that once these lesions have become extensive or severe enough to produce clinical features, inhibition of the atherosclerotic process may not necessarily prolong life. Arising from these considerations are several major problems. First, there is as yet no entirely satisfactory means for the continued control of the circulating lipids and lipoproteins; second, there is no conclusive evidence that such control will retard the atherosclerotic process; and third, there is little indication that, once the clinical disease has become manifest, inhibition of the atherosclerotic process will alter prognosis.
At present there are two principal challenges. It is necessary to develop methods that will detect with certainty which apparently healthy individuals will ultimately complain of the features of ischaemic heart disease. If it should be established that regulation of the circulating lipids and lipoproteins is desirable and beneficial, it will be necessary to have available an efficient and acceptable treatment which will maintain this control on a long-term basis.

\section{Summary}

I. The nature of the circulating lipids and lipoproteins is described.

2. The influence of age, sex, race and diet on the circulating lipids and lipoproteins is considered.

3. The association of elevation of the plasma cholesterol, of the $\mathrm{C} / \mathrm{P}$ ratio and of the concentration of cholesterol on the $\beta$-lipoproteins with clinical coronary artery disease is discussed.

4. Methods are available for controlling these abnormal lipid and lipoprotein patterns, but such control may not change life expectancy.

\section{BIBLIOGRAPHY}

AHRENS, E. H., and KUNKEL, H. G. (r949), F. exp. Med., 9o, 409.

ANDERsoN, J. T., and KEYs, A. (1953), Fed. Proc., 12, 169. ANITSCHKOW, N. (i 933), 'Arteriosclerosis,' E. V. Cowdro Macmillan, N.Y., $27 \mathrm{I}$.

ANITSCHKOW, $\mathrm{N}$. , and CHALATOW, S. (I913), Zbl. allse Path. path. Anat., 24, I.

BARR, D. P., RUSS, E. M., and EDER, H. A. (I95 I), Amer. $F$ Med., II, 480.

BEVERIDGE, J. M. R., CONNELL, W. F., MAYER, G. A., FIRSTBROOK, J. B., and DEWOLFE, M. S. (I955), $\mathscr{7}$. Nutr., 56, 3 I I.

BIGGS, M. W., KRITCHEVSKY, D., COLMAN, D., GOFMAN, J. W., JONES, H. B., LINDGREN, F. T., HYDE, G., and LYON, 'T. P.'(1952), Circulation, 6, 359.

BLIX, G., TISELIUS, A., and SVENSSON, H. (I94I), $\mathfrak{f}$. biol. Chem., 137, 485 .

BOYD, E. M. (1937), Trans. roy. Soc. Can., 31, Sect. 5, I I.

BOYD, G. S. (1954), Biochem. F., 58, 68 o.

BRAGDON, J. H. (195I), Circulation, 4, 466 .

BRON'TE-STEWART, B., ANTONIS, A., EALES, L., and BROCK, J. F. (1956), Lancet, i, 521 .

BUCK, R. C., and ROSSITER, R. J. (I95I), Arch. Path., 51, 224. 㝋

COHN, E. J., GURD, F. R. N., SURGENOR, D. M., BARNES, B.' A., BROWN, R. K., DEROUAUX, G., GILLESPIE, J. M., KAHNT, F. W., LEVER, W. F., LIU, C. H., LROMA, E. (1950), 'F. Amer. chem. Soc., 72, 465.

DURRUM, E. L. (I950), F. Amer. chem. Soc., 72, 2943.

(iER'TLER, M. M., GARN, S. M., and LERMAN, J. (1950), I Circulation, 2, 205.

GOFMAN, J. W., LINDGREN, F. T., and ELLIO'T, H. (I949), F. biol. Chem., 179, 973 .

GOFMAN, J. W. GLAZIER, F. TAMPLIN, A., STRISOWER, O B., and DELALLA, O. (1954), Physiol. Rev., 34, 589.

JONES, H. B., GOFMAN, J. W., LINDGREN, F. T., LYON, S T. P., GRAHAM, D. M., S'TRISOWER, B., and NICHOLS, $\omega$ A. V. (195 I), Amer. $\mathcal{F}$. Med., I I, 358.

KARTIN, B. L., MAN, E. B., WINKLER, A. W., and PETERS, J. P. ( I 944$), \%$ clin. Invest, , 23, 824 .

KATZ, L. N., an: 'TAMLER, J. (I953), 'Experimental Atherosclerosis,' Chas. C. Thomas, Springfield, i I I.

KEYS, A. MICKELSEN, O., MILlER, E. O., HAYES, E. R., and TODD, R. L. (1950), F. clin. Invest., 29, 1347.

KEYS, A., ANDERSON, J. 'T., MICKELSEN, O., ADELSON, S. F., and FIDANZA, F. (I956), F. Nutr., 59, 39.

Continued on page 26 
bandaged loosely or left uncovered under a cage with a light dressing over the ulcer. Patients with arteriosclerosis often complain when in bed of burning pain in the lower limb (erythralgia) and may prefer to sleep with their legs uncovered by bedclothes. Bandaging only makes such a condition worse. Nevertheless, the body should be warmly clad to keep vasomotor tone low and it is probable that smoking is best prohibited.

The local treatment is similar to that for venous ulcers, though an ointment containing cod liver oil or irradiated sterol is sometimes useful for the arterial type.

In the treatment of arteriosclerotic ulcers vasodilator drugs are worth a trial and are found by some to be most effective when given intraarterially. In hypertensive patients side-effects have been described but seem uncommon, and for those with hypertensive ulcers treatment aimed to reduce the hypertension should be given.

Buerger's postural exercises should be given a trial, but intermittent venous compression is not of value. Sympathectomy should be considered if sympathetic block causes an increase in the temperature of the limb. A small proportion of arteriosclerotic ulcers may be healed by such measures, but unfortunately a greater proportion require amputation.

\section{Summary}

The prevention of leg ulcers is discussed with particular reference to the prevention of venous thrombosis. In the treatment of venous ulcers the importance of getting rid of oedema is stressed and various methods of doing so are mentioned, especially that of compression. Local treatment of the ulcer is shown to be a matter of secondary importance. Surgical treatment is briefly dis- cussed. The treatment of arterial ulcers iscon mentioned.

\section{BIBLIOG RAPHY}

ANNING, S. T. (r954), ' Leg Llcers: Their lauses and Treatment,' London, Churchill.

BAUER, G. (1942), Acta chir. scand., 86, suppl. 74.

BALER, G. (1946), Lancet, i, 447 .

BAUER, G. (1948), f. int. Chir., 8, 937.

BISGAARD, H. (I948), 'Ulcers and Eczema of the Len, etc..' Copenhagen, Munksgaard.

BOYD, A. M., JEPSON, R. P., RATCLIFFE, A. H., and ROSE, S. S. (1952), Angiology, 3, 207.

BREWER, A. C. ( I 950), Brit. med. F., ii, 270.

COCKETT, F. B., and JONES, D. E. E. (1953), Lancet, i, I 7

COCKETT, F. B. (I955), Brit. F. Surg., 43, 260.

COURSLEY, G., IVINS, J. C., and BARKER, N. W. (1956), Angiology', 7,201.

CRITCHE'TT, G. (1849), 'Lectures on the Cause and Treatment of Ulcers of the Lower Extremity,'London, Churchill.

DODD, H., and COCKETT, F. B. (1956), "The Pathology and Surgery of the Veins of the Lower Limb,' Edinburgh, Livingstone.

GAY, J. (I868), 'On Varicose Diseases of the Lower Extremities: 'The Lettsomian Lectures of 1867 ,'London, Churchill.

HILTON, J. (186I), Lancet, ii, 245.

H $\phi$ JENSGÅRD, I. C. (1952), Angiology, 3, 42.

H $\phi$ JENSGARD, I. C., and STURUP, H. (I952), Acta phlsiol scand., 27, 49.

HUN'T, T. (r859), 'A Guide to the Treatment of Diseases of the iN Skin,' 4th Edition, London, Richards.

MARTORELL, F. (1945), Actas del I. Policlinico, cited by Martorell (1950).

MARTORELL, F. (1950), Angiology', I, 133.

MARTORELL, F. (r953), 'Ulcera hipertensiva,' Barcelona, Col. española de Monografias medicas.

MOORE, H. D. (195I), Lancet, ii, 7.

PIULACHS, P., and VIDAL-BARRAQUER, F. (1953), Angiolog. 4, 59.

RAMAZZININI, B. (1705), 'A Treatise of the Diseases of Trade men,' London, Bell et al.

SERVELLE, M. (1950), Sem. Hôp. (Paris), 26, 2483.

SPENDER, J. K. (1868), A Manual of the Pathology and Treat? ment of Ulcers and Cutaneous Diseases of the Lower Limbs, London, Churchill.

VERNEUIL, A. (1855), Gaz. méd. (Paris), 10, 524.

VICARY, T. ( 1636$)$, 'The Englishman's Treasure,' London, Alsop and Fawcet.

VOGLER, E., and GOLLMAN, G. (I955), Angiology, 6, 540.

WALKER, A. J. (1950), Brit. med. F., ii, 1307.

WHITE, R. P. (1918), Brit. F. Derm., 30, 138.

WOODALL, J. (I639), 'Manual of Military and Domestique Surgery,' London, Bourne.

WRIGHT, A. DICKSON (1930), Brit. med. F., ii, 996.

Bibliography continued from page 6, M. F. Oliver, M.B., M.R.C.P.E., and G. S. Boyd, Ph.D.

KINSELL, L. W., MICHAELS, G. D., PARTRIDGE, J. W., BOLING, L. A., BALCH, H. E., and COCHRANE, G. C'. (1953), Amer. F. clin. Nutr., 1, 224; (1955), Nutr. Rev., 13,8.

I.INDGREN, F. T., ELLIOT, H., and GOFMAN, J. W. (1951), F. phys. Chem., 179, 973.

MACHEBOEUF, M. (1929), Bull. Soc. Chim. biol., Paris, xI, 268. MELLINKOFF, S. M., MACHELLA, T. E., and REINHOLD, J. G. (1950), Amer. f. med. Sci., 220, 203.

MORRISON, L. M., GONZALEZ, P., and WOLFSON, E. (1950), Circulation, 2, 472

NIKKILX, E. (1953), Scand. F. c'in. Lab. Invest, 5, suppl. 8. OLIVER, M. F. In preparation.

OLIVER, M. F., and BOYD, G. S. (1953a), Clin. Sci., 12, 217. OLIVER, M. F., and BOYD, G. S. (1953b), Brit. Heart F., 15, 387. OLIVER, M. F., and BOYD, G. S. (1955a), Clin. Sci., 14, 5. OLIVER, M. F., and BOYD, S. G. (1955b), Brit. Heart F., 17, 299. OLIVER, M. F., and BOYD, G. S. (1955 C), Minn. Med., 38, 7.94; Symposium on Arteriosclerosis, Minnesota Heart Association, 64.

OPHULS, W. (1933), 'Arteriosclerosis,' E. V. Cowdry, Macmillan, N.Y., 249.
PAGE, I. H., KIRK, E., LEWIS, W. H. THOMPSON, W. R and VAN SLYKE, D. D. (1935), F. biol. Chem., II1, 613 . PETERS, J. P., and MAN, E. B. (1943), F. clin. Invest., 22, 707. POLLAK, O. J. (1949), Amer. Heart F., 38, 459. ROSENBERG, I. N., YOUNG, E., and PROGER, S. (1954),
Amer. $\mathscr{Y}$. Med., r6, 818 .

RUBIN, L., and ALADJEM, F. (1954), Amer. F. Physiol, 178, 263. RUSS, E. M., EDER, H. A., and BARR, D. P. (1951), Amer. $\mathcal{f}$ Med., II, 468.

SPERRY, W. M. (1936), F. biol. Chem., 114, 125.

SPERRY, W. M., and WEBB, M. (1950), F. biol. Chem., 187, 107. STEINER, A., KENDALL, F. E., and MATHERS, J. A. L. (1952), Circulation, 5, 605.

SWAHN, B. (1952), Scand. F. clin. Lab. Invest., 4, 98.

SWAHN, B. (I I953), Scand. F. clin. Lab. Invest., 5, Suppl. 9.

VIRCHOW, R. (1856), Gesamm. Abh. z. wiss. Med., 14, 458.

VOGEL, J. (1847), 'The Pathological Anatomy of the Human Body,' Lea \& Blanchard, Philadelphia. WEINHOUSE, S., and HIRSCH, E. F. (1940), Arch. Path., 30,
856.

WIELAND, T., and FISCHER, E. (1948), 'Naturwissenschaften,' $35,29$. 